УДК 519.9 : 37.0153

Іванюта Ольга

кандидат психологічних наук, доцент, доцент кафедри психології Міжнародного економіко-гуманітарного університету імені академіка Степана Дем'янчука https://orcid.org/0000-0002-3316-9879

Яницька Олена кандидат педагогічних наук, доцент, професор кафедри психології Міжнародного економіко-гуманітарного університету імені академіка Степана Дем'янчука https://orcid.org/0000-0003-4965-1720 DOI https://doi.org/10.35619/praprv.v1i15.185

\title{
ПСИХОЛОГІЧНИЙ АСПЕКТ СФОРМОВАНОСТІ ВІЗУАЛЬНОГО МИСЛЕННЯ У ШКОЛЯРІВ ПІДЛІТКОВОГО ВІКУ
}

У статті подано результати інтерпретаиії індивідуальних даних сформованості візуального мислення школярів підліткового віку методом визначення внутрішньо-групової норми. Співставлено результати дослідження, отримані за методикою Торренса $і$ Равена, щзо дозволило визначити рівень розвитку візуального мислення кожного досліджуваного $i$ виявити підлітків з низьким показником продуктивності візуальної мисленнєвої діяльності, щุo є надзвичайно важливим для впровадження технологій стимулювання візуального мислення підлітків.

Ключові слова: візуальне мислення, внутрішньо-групова норма, методика Торренса, методика Равена, піктограма.

Постановка проблеми. Актуальність розвитку візуального мислення визначається тим, що цей процес займає особливе місце в інтелектуальному i творчому розвитку особистості. Виявлення варіативності у результатах показників процесуальних, операціональних та змістових компонентів візуального мислення підлітків забезпечує можливість для виокремлення чотирьох груп досліджуваних, що є надзвичайно важливим для розробки програми та технології стимулювання візуального мислення підлітків.

Аналіз останніх досліджень і публікацій. У вітчизняній психолого-педагогічній науці дослідження візуального мислення проведено за декількома показниками: вивчення механізмів візуального мислення як складової функціональної системи операцій (Роєм [1]) простеження ролі візуалізації у процесі вирішення творчих завдань у конструкторській діяльності (Моляко); дослідження особливостей трансформацій візуального образу в художньо-графічній діяльності (Симоненко [2]); виокремлення особливостей візуальної медіа культури (Череповська [3]).

Найбільш поширеним у вітчизняній психологічній науці $є$ визначення візуального мислення, як специфічного виду інтелектуальної діяльності, змістом якої є оперування та маніпулювання зоровими (візуальними) образами, а результатом - створення нових образів, що несуть змістове навантаження й роблять значення видимим.

Формулювання цілей статті. Метою дослідження є визначення рівня сформованості візуального мислення у школярів підліткового віку та виявлення серед досліджуваних тих підлітків, які потребують психологічної допомоги в розвитку візуальної мисленнєвої діяльності.

Для визначення вікового генезу процесів візуального мислення нами були використані середні показники в кожній групі. Все ж, такий метод не дає можливості для співставлення індивідуальних результатів досліджуваних із загально віковими показниками. 
Для більш об’єктивної інтерпретації індивідуальних даних ми скористалися методом визначення внутрішньо групової норми.

Показник внутрішньо групової норми дозволяє оцінити успішність кожного підлітка у співвідношенні з тієї віковою групою, до якої він належить. Цей показник визначається за допомогою процентилів. Оцінка результативності у процентилях дає можливість розподілити роботи учнів за чотирма квартилями $\mathrm{i}$, таким чином, визначити успішність кожного учня як низьку (Н - I квартиль), нижче середньої (ВС - III квартиль) або високу (В IV квартиль). Застосувавши показник внутрішньогрупової норми, маємо можливість виявити підлітків 3 низькими та нижче середнього рівнями розвитку візуального мислення й виокремити їх у окрему групу.

Для визначення загального рівня розвитку візуального мислення підлітків ми співставили результати, отримані за допомогою методик Торренса і Равена, оскільки саме ці методики було застосовано для визначення кількісних показників розвитку процесуальних характеристик та операційних структур візуального мислення. При вивченні змістових компонентів візуального мислення нас, у першу чергу, цікавив якісний аналіз, тому ми не використовували критерій внутрішньо групової норми для оцінки результатів піктографічного тестування.

Результативність виконання завдань молодшими підлітками (M=10,1 років) на етапі констатувального та формувального експериментів представлено у таблиці 1.

Табличя 1

Зміна показників візуального мислення у підлітків першої вікової підгрупи (М=10,1 років) під впливом спеціально організованого навчання (за методикою Торренса)

\begin{tabular}{|c|c|c|c|c|c|c|c|c|c|}
\hline \multirow[t]{3}{*}{ № } & \multirow[t]{3}{*}{$\begin{array}{c}\text { Дослідж } \\
\text { увані }\end{array}$} & \multicolumn{8}{|c|}{$\begin{array}{c}\text { Показники сформованості основних ознак візуального мислення до і } \\
\text { після розвивальної роботи (у балах) }\end{array}$} \\
\hline & & \multicolumn{2}{|c|}{$\begin{array}{c}\text { активність } \\
\text { висування } \\
\text { гіпотез }\end{array}$} & \multicolumn{2}{|c|}{$\begin{array}{l}\text { категоріальна } \\
\text { гнучкість }\end{array}$} & \multicolumn{2}{|c|}{$\begin{array}{l}\text { конструктивна } \\
\text { активність }\end{array}$} & \multicolumn{2}{|c|}{ оригінальність } \\
\hline & & до & після & до & після & до & після & до & після \\
\hline 1 & Ж.Ю. & 22 & 28 & 15 & 20 & 41 & 48 & 38 & 45 \\
\hline 2 & Ю.Ю & 29 & 34 & 15 & 18 & 39 & 45 & 38 & 43 \\
\hline 3 & Л.С. & 24 & 32 & 13 & 18 & 31 & 44 & 31 & 47 \\
\hline 4 & Д.С. & 23 & 30 & 14 & 16 & 38 & 50 & 32 & 40 \\
\hline 5 & M.I. & 24 & 27 & 13 & 17 & 38 & 46 & 37 & 42 \\
\hline 6 & O.I. & 26 & 30 & 15 & 19 & 38 & 44 & 33 & 42 \\
\hline 7 & К.Ю. & 21 & 29 & 9 & 14 & 32 & 47 & 28 & 39 \\
\hline 8 & Г.Л. & 27 & 34 & 14 & 18 & 40 & 47 & 26 & 34 \\
\hline 9 & C.M. & 25 & 30 & 15 & 18 & 43 & 50 & 35 & 44 \\
\hline 10 & Т.Ю. & 20 & 27 & 12 & 16 & 37 & 49 & 35 & 40 \\
\hline 11 & I.B. & 18 & 28 & 11 & 17 & 27 & 45 & 39 & 43 \\
\hline 12 & K.O. & 19 & 26 & 10 & 15 & 35 & 43 & 37 & 47 \\
\hline & $\mathrm{x}$ & 23,2 & 29,6 & 13,0 & 17,2 & 36,6 & 46,5 & 34,1 & 42,2 \\
\hline & $\delta$ & 3,33 & 2,64 & 2,09 & 1,70 & 4,58 & 2,39 & 4,17 & 3,64 \\
\hline & $\mathrm{t}$ & \multicolumn{2}{|c|}{5,25} & \multicolumn{2}{|c|}{5,42} & \multicolumn{2}{|c|}{6,66} & \multicolumn{2}{|c|}{5,06} \\
\hline
\end{tabular}


Співставлення результатів, отриманих за двома методиками, показало, що в залежності від того чи іншого показника, до IV квартилю (рівень В) можна віднести від 17 \% до 30 \% досліджуваних; до III квартилю (рівень ВС) від 20 \% до 27 \%; до М II квартилю (рівень НС) від $23 \%$ до $30 \%$; до I квартилю (рівень Н) від $23 \%$ до $27 \%$. До експериментальної групи ми зарахували 12 досліджуваних (відповідно 40 \%).

Результативність виконання завдань 11-річними підлітками представлена у таблиці 2.

Таблиия 2

Зміна показників візуального мислення у підлітків другої вікової підгрупи (М=11 років) під впливом спеціально організованого навчання (за методикою Торренса)

\begin{tabular}{|c|c|c|c|c|c|c|c|c|c|}
\hline \multirow[t]{3}{*}{ № } & \multirow[t]{3}{*}{ Досліджувані } & \multicolumn{8}{|c|}{$\begin{array}{c}\text { Показники сформованості основних ознак візуального мислення } \\
\text { до і після розвивальної роботи (у балах) }\end{array}$} \\
\hline & & \multicolumn{2}{|c|}{$\begin{array}{c}\text { активність } \\
\text { висування } \\
\text { гіпотез } \\
\end{array}$} & \multicolumn{2}{|c|}{$\begin{array}{c}\text { категоріальна } \\
\text { гнучкість }\end{array}$} & \multicolumn{2}{|c|}{$\begin{array}{c}\text { конструктивна } \\
\text { активність }\end{array}$} & \multicolumn{2}{|c|}{ оригінальність } \\
\hline & & до & після & до & після & до & після & до & після \\
\hline 1 & Х.Д. & 30 & 34 & 15 & 19 & 45 & 50 & 32 & 45 \\
\hline 2 & Ш.П. & 27 & 39 & 14 & 17 & 40 & 51 & 39 & 50 \\
\hline 3 & Ш.В. & 27 & 34 & 12 & 18 & 44 & 50 & 35 & 39 \\
\hline 4 & C.O. & 29 & 33 & 13 & 16 & 43 & 51 & 36 & 44 \\
\hline 5 & O.B. & 20 & 23 & 12 & 17 & 33 & 42 & 29 & 37 \\
\hline 6 & K.A. & 17 & 24 & 10 & 15 & 26 & 40 & 28 & 34 \\
\hline 7 & 3.O. & 25 & 28 & 11 & 17 & 44 & 49 & 35 & 44 \\
\hline 8 & C.M. & 29 & 35 & 11 & 14 & 32 & 41 & 28 & 38 \\
\hline 9 & K.T. & 22 & 26 & 9 & 15 & 37 & 43 & 27 & 40 \\
\hline 10 & П.Р. & 26 & 35 & 14 & 20 & 43 & 50 & 29 & 34 \\
\hline 11 & П.Н. & 28 & 33 & 14 & 19 & 40 & 46 & 37 & 47 \\
\hline 12 & 3.Д. & 25 & 31 & 13 & 15 & 37 & 42 & 26 & 33 \\
\hline & $\mathrm{x}$ & 25,4 & 31,3 & 12,3 & 16,8 & 38,7 & 46,3 & 31,8 & 40,4 \\
\hline & $\delta$ & 3,94 & 4,94 & 1,83 & 1,90 & 5,88 & 4,35 & 4,45 & 5,55 \\
\hline & $\mathrm{T}$ & & 3,20 & & & 3,59 & & 4,23 & \\
\hline & & & & & & & & & \\
\hline
\end{tabular}

Співставлення успішності показало, що в залежності від різних показників, до IV квартилю (В) та III квартилю (ВС) ми можемо віднести від 13 \% до 27 \% досліджуваних; до II квартилю (НС) від $20 \%$ до 33\%; до I квартилю (Н) від $27 \%$ до $30 \%$ \%. До експериментальної групи ми включили 12 досліджуваних (40 \%).

У таблиці 3 подані результати виконань завдань методики Торренса на етапі констатувального і формувального експериментів підлітками третьої вікової підгрупи (М=12 років). 
Таблиия 3

Зміна показників візуального мислення у третій віковій підгрупі підлітків (М=12 років) під впливом спеціально організованого навчання (за методикою Торренса)

\begin{tabular}{|c|c|c|c|c|c|c|c|c|c|}
\hline \multirow[t]{3}{*}{ № } & \multirow[t]{3}{*}{ Досліджувані } & \multicolumn{8}{|c|}{$\begin{array}{c}\text { Показники сформованості основних ознак візуального мислення } \\
\text { до і після розвивальної роботи (у балах) }\end{array}$} \\
\hline & & \multicolumn{2}{|c|}{$\begin{array}{c}\text { активність } \\
\text { висування } \\
\text { гіпотез } \\
\end{array}$} & \multicolumn{2}{|c|}{$\begin{array}{c}\text { категоріальна } \\
\text { гнучкість }\end{array}$} & \multicolumn{2}{|c|}{$\begin{array}{c}\text { конструктивна } \\
\text { активність }\end{array}$} & \multicolumn{2}{|c|}{ оригінальність } \\
\hline & & до & після & до & після & до & після & до & після \\
\hline 1 & Д.М. & 31 & 40 & 16 & 20 & 62 & 76 & 32 & 48 \\
\hline 2 & П.О. & 34 & 37 & 17 & 19 & 48 & 58 & 33 & 45 \\
\hline 3 & 3.M. & 32 & 36 & 16 & 21 & 55 & 68 & 27 & 42 \\
\hline 4 & Д.Ю. & 36 & 40 & 20 & 21 & 50 & 59 & 34 & 48 \\
\hline 5 & Л.О. & 39 & 40 & 18 & 23 & 31 & 50 & 37 & 45 \\
\hline 6 & Ш.I. & 29 & 34 & 15 & 17 & 58 & 67 & 29 & 41 \\
\hline 7 & С.П. & 38 & 40 & 18 & 19 & 58 & 61 & 34 & 40 \\
\hline 8 & Ш.С. & 33 & 40 & 14 & 17 & 55 & 60 & 28 & 42 \\
\hline 9 & C.A. & 35 & 40 & 12 & 18 & 60 & 67 & 34 & 41 \\
\hline 10 & Д.О. & 30 & 39 & 17 & 20 & 59 & 71 & 28 & 37 \\
\hline 11 & Л.В. & 37 & 40 & 13 & 17 & 47 & 55 & 37 & 41 \\
\hline & $\mathrm{x}$ & 34,0 & 38,7 & 16,0 & 19,3 & 53,0 & 62,9 & 32,1 & 42,7 \\
\hline & $\delta$ & 3,32 & 2,10 & 2,37 & 1,95 & 8,82 & 7,60 & 3,59 & 3,41 \\
\hline & $\mathrm{t}$ & \multicolumn{2}{|c|}{4,01} & \multicolumn{2}{|c|}{3,52} & \multicolumn{2}{|c|}{2,82} & \multicolumn{2}{|c|}{7,14} \\
\hline & & & & $p=2$ & $p=$ & & & & \\
\hline
\end{tabular}

Iз підлітків 12 років до IV i III кварталів (B-BC) за різними показниками ми зарахували від 17 \% до 27 \% досліджуваних; до II квартилю (НC) від 20 \% до 73 \%; до I квартилю $(\mathrm{H})$ від $20 \%$ до 30 \%. До експериментальної групи 3 12-річних увійшли 11 досліджуваних (37 \%).

Результати підлітків 13 років представлені в табл. 4.

Таблиия 4

Зміна показників візуального мислення у четвертій віковій підгрупі підлітків (М=13 років) під впливом спеціально організованого навчання (за методикою торренса)

\begin{tabular}{|c|c|c|c|c|c|c|c|c|c|}
\hline \multirow[t]{3}{*}{ № } & \multirow[t]{3}{*}{$\begin{array}{l}\text { Досліджу } \\
\text { вані }\end{array}$} & \multicolumn{8}{|c|}{$\begin{array}{l}\text { Показники сформованості основних ознак візуального мислення до і } \\
\text { після розвивальної роботи (у балах) }\end{array}$} \\
\hline & & \multicolumn{2}{|c|}{$\begin{array}{c}\text { активність } \\
\text { висування } \\
\text { гіпотез } \\
\end{array}$} & \multicolumn{2}{|c|}{$\begin{array}{c}\text { категоріальна } \\
\text { гнучкість }\end{array}$} & \multicolumn{2}{|c|}{$\begin{array}{c}\text { конструктивна } \\
\text { активність }\end{array}$} & \multicolumn{2}{|c|}{ оригінальність } \\
\hline & & до & після & до & після & до & після & до & після \\
\hline 1 & П.О. & 38 & 39 & 18 & 20 & 55 & 60 & 40 & 42 \\
\hline 2 & T.O. & 37 & 40 & 18 & 22 & 53 & 67 & 39 & 44 \\
\hline 3 & H.B. & 36 & 38 & 16 & 19 & 50 & 57 & 22 & 33 \\
\hline 4 & Д.В. & 38 & 40 & 15 & 17 & 51 & 64 & 37 & 41 \\
\hline 5 & C.I. & 35 & 36 & 19 & 20 & 55 & 62 & 40 & 46 \\
\hline
\end{tabular}




\begin{tabular}{|c|c|c|c|c|c|c|c|c|c|}
\hline 6 & C.C. & 32 & 36 & 17 & 19 & 48 & 59 & 25 & 38 \\
\hline 7 & C.A. & 39 & 40 & 20 & 20 & 60 & 65 & 45 & 47 \\
\hline 8 & O.H. & 38 & 38 & 20 & 21 & 58 & 73 & 43 & 50 \\
\hline 9 & В.Л. & 38 & 40 & 17 & 18 & 49 & 58 & 30 & 34 \\
\hline 10 & Я.П. & 35 & 37 & 19 & 21 & 60 & 76 & 43 & 51 \\
\hline 11 & С.Д. & 39 & 40 & 17 & 20 & 57 & 65 & 45 & 49 \\
\hline 12 & C.B. & 34 & 37 & 19 & 23 & 57 & 69 & 28 & 34 \\
\hline 13 & C.P. & 40 & 40 & 19 & 20 & 58 & 74 & 42 & 53 \\
\hline 14 & K.C. & 38 & 40 & 18 & 21 & 58 & 69 & 38 & 46 \\
\hline & $\mathrm{x}$ & 36,93 & 38,64 & 18,00 & 20,07 & 54,93 & 65,57 & 36,93 & 43,43 \\
\hline & $\delta$ & 2,23 & 1,60 & 1,60 & 1,54 & 4,07 & 6,09 & 7,58 & 6,64 \\
\hline & $\mathrm{t}$ & \multicolumn{2}{|c|}{2,34} & \multicolumn{2}{|c|}{3,63} & \multicolumn{2}{|c|}{5,43} & \multicolumn{2}{|c|}{2,42} \\
\hline
\end{tabular}

За показника методики Торренса до IV квартилю (В) включено від $17 \%$ до 27 \% досліджуваних; до III квартилю (ВС) від 20 \% до 30 \%; до II квартилю (НС) від 23 \% до 63 \%; до I квартилю (Н) від 27 \% до 37 \%. Низькі (І квартиль) та нижче середніх (II квартиль) результати за двома методиками показали 14 досліджуваних (47 \%).

Співставлення результатів підлітків 14 років показало (табл. 5), що до IV i III кварталів (В-BC) можна віднести, в залежності від показників, від $10 \%$ до $33 \%$ досліджуваних; до II квартилю (НС) від 20 \% до 67 \%; до I квартилю (Н) від 27 \% до 33 \%. До експериментальної групи ми включили 15 досліджуваних (50\%).

Таблиия 5

Зміна показників візуального мислення у п'ятій віковій підгрупі підлітків (M=14 років) під впливом спеціально організованого навчання (за методикою Торренса)

\begin{tabular}{|c|c|c|c|c|c|c|c|c|c|}
\hline \multirow[t]{3}{*}{ № } & \multirow[t]{3}{*}{$\begin{array}{l}\text { Досліджу } \\
\text { вані }\end{array}$} & \multicolumn{8}{|c|}{$\begin{array}{l}\text { Показники сформованості основних ознак візуального мислення до і } \\
\text { після розвивальної роботи (у балах) }\end{array}$} \\
\hline & & \multicolumn{2}{|c|}{$\begin{array}{c}\text { активність } \\
\text { висування } \\
\text { гіпотез }\end{array}$} & \multicolumn{2}{|c|}{$\begin{array}{l}\text { категоріальна } \\
\text { гнучкість }\end{array}$} & \multicolumn{2}{|c|}{$\begin{array}{c}\text { конструктивна } \\
\text { активність }\end{array}$} & \multicolumn{2}{|c|}{ оригінальність } \\
\hline & & до & після & до & після & до & після & до & після \\
\hline 1 & П.Т. & 35 & 40 & 15 & 19 & 45 & 60 & 32 & 37 \\
\hline 2 & K.P. & 37 & 40 & 16 & 19 & 51 & 58 & 39 & 51 \\
\hline 3 & 3.O. & 39 & 40 & 19 & 20 & 69 & 74 & 43 & 54 \\
\hline 4 & Б.C. & 35 & 36 & 17 & 21 & 55 & 56 & 37 & 40 \\
\hline 5 & T.O. & 40 & 40 & 20 & 20 & 66 & 75 & 43 & 49 \\
\hline 6 & Я.O. & 40 & 40 & 20 & 24 & 69 & 71 & 47 & 55 \\
\hline 7 & K.M. & 37 & 37 & 15 & 18 & 56 & 63 & 28 & 40 \\
\hline 8 & П.Г. & 38 & 40 & 18 & 23 & 57 & 61 & 42 & 54 \\
\hline 9 & M.T. & 36 & 39 & 18 & 19 & 64 & 69 & 41 & 44 \\
\hline 10 & C.A. & 38 & 40 & 18 & 22 & 60 & 63 & 41 & 49 \\
\hline 11 & 3.Д. & 36 & 38 & 11 & 14 & 39 & 51 & 35 & 41 \\
\hline 12 & В.Д. & 38 & 40 & 11 & 16 & 62 & 69 & 24 & 35 \\
\hline 13 & C.O. & 38 & 40 & 19 & 21 & 68 & 72 & 38 & 49 \\
\hline 14 & 3.T. & 39 & 39 & 20 & 21 & 63 & 72 & 40 & 45 \\
\hline 15 & П.Ж. & 40 & 40 & 21 & 26 & 64 & 77 & 43 & 50 \\
\hline & $\mathrm{X}$ & 37,73 & 39,27 & 17,20 & 20,20 & 59,20 & 66,07 & 38,20 & 46,20 \\
\hline & $\delta$ & 1,71 & 1,28 & 3,10 & 3,00 & 8,84 & 7,79 & 6,19 & 6,44 \\
\hline & $\mathrm{t}$ & \multicolumn{2}{|c|}{2,80} & \multicolumn{2}{|c|}{2,70} & \multicolumn{2}{|c|}{2,26} & \multicolumn{2}{|c|}{3,48} \\
\hline \multicolumn{10}{|c|}{$t_{k p}=2,05 ; p=0,05$} \\
\hline
\end{tabular}


Серед 15-річних (табл. 6) за показниками методики Торренса до IV і III кварталів (BВC) зараховано від 20 \% до 73 \%; до II квартилю (НС) від $27 \%$ до 73\%; до I квартилю (Н) 27 \%. До експериментальної групи увійшло 16 досліджуваних (53 \%).

Таким чином, оцінка індивідуальних результатів виконання тестових завдань підлітками 10-15 років за критерієм внутрішньо групової норми дозволила визначити рівень розвитку візуального мислення кожного досліджуваного й виявити підлітків із низькими показниками продуктивності візуальної мисленнєвої діяльності, у результаті чого було виділено експериментальну групу. Проте для більш повної інтерпретації особливостей розвитку візуального мислення підлітків з низькими оцінками успішності ми звернули увагу й на якісні характеристики. Аналізуючи роботи підлітків, які увійшли до експериментальної групи, відзначимо деякі загальні риси, на яких потрібно зупинитися докладніше.

Методика Торренса. Візуальне мислення підлітків експериментальної групи характеризується, у першу чергу, ригідністю перцептивно-мисленнєвої діяльності. Ця особливість виявляється під час аналізу всіх показників даної методики. Так, низькі оцінки активності висування візуальних гіпотез одержали не лише ті підлітки, які відмовилися від роботи 3 певними фігурами, але й ті, які створили образи, неадекватні даному стимулу. Наприклад, досліджуваний Д.М. (12 років) на паралельних лініях (III стимул) малює квітку й називає цей малюнок «Альбом». Формально завдання виконано: створено образ, дано назву. Але при цьому підліток практично ігнорує поданий стимульний матеріал.

Таблиця 6

Зміна показників візуального мислення у шостій віковій підгрупі підлітків (M=15 років) під впливом спеціально організованого навчання (за методикою Торренса)

\begin{tabular}{|c|c|c|c|c|c|c|c|c|c|}
\hline \multirow[t]{3}{*}{ № } & \multirow[t]{3}{*}{$\begin{array}{l}\text { Досліджу } \\
\text { вані }\end{array}$} & \multicolumn{8}{|c|}{$\begin{array}{l}\text { Показники сформованості основних ознак візуального мислення до і } \\
\text { після розвивальної роботи (у балах) }\end{array}$} \\
\hline & & \multicolumn{2}{|c|}{$\begin{array}{c}\text { активність } \\
\text { висування } \\
\text { гіпотез }\end{array}$} & \multicolumn{2}{|c|}{$\begin{array}{c}\text { категоріальна } \\
\text { гнучкість }\end{array}$} & \multicolumn{2}{|c|}{$\begin{array}{c}\text { конструктивна } \\
\text { активність }\end{array}$} & \multicolumn{2}{|c|}{ оригінальність } \\
\hline & & до & після & до & після & до & після & до & після \\
\hline 1 & Л.P. & 40 & 40 & 21 & 23 & 65 & 72 & 43 & 48 \\
\hline 2 & П.Р. & 35 & 38 & 16 & 21 & 60 & 74 & 36 & 47 \\
\hline 3 & M.A. & 40 & 40 & 20 & 23 & 69 & 77 & 47 & 53 \\
\hline 4 & Л.Н. & 39 & 40 & 21 & 21 & 65 & 78 & 42 & 54 \\
\hline 5 & Ш.В. & 37 & 40 & 19 & 20 & 61 & 66 & 36 & 43 \\
\hline 6 & Я.P. & 36 & 39 & 16 & 19 & 44 & 58 & 34 & 40 \\
\hline 7 & P.B. & 39 & 40 & 15 & 19 & 55 & 67 & 37 & 44 \\
\hline 8 & П.О. & 38 & 40 & 17 & 22 & 51 & 61 & 33 & 41 \\
\hline 9 & Ш.Т. & 37 & 40 & 15 & 17 & 58 & 63 & 37 & 49 \\
\hline 10 & T.B. & 40 & 40 & 19 & 21 & 66 & 79 & 44 & 49 \\
\hline 11 & Д.О. & 40 & 40 & 20 & 25 & 61 & 69 & 46 & 55 \\
\hline 12 & A.A. & 40 & 40 & 18 & 22 & 63 & 70 & 44 & 45 \\
\hline 13 & K.I. & 40 & 40 & 17 & 18 & 49 & 65 & 38 & 47 \\
\hline 14 & P.T. & 36 & 40 & 21 & 24 & 70 & 74 & 46 & 51 \\
\hline 15 & С.Д. & 40 & 40 & 21 & 22 & 63 & 69 & 47 & 50 \\
\hline 16 & K.B. & 40 & 40 & 18 & 20 & 70 & 81 & 40 & 44 \\
\hline & $\mathrm{x}$ & 38,56 & 39,56 & 18,38 & 21,06 & 60,63 & 70,19 & 40,63 & 47,50 \\
\hline & $\delta$ & 1,79 & 0,54 & 2,19 & 2,17 & 7,61 & 6,72 & 4,81 & 4,49 \\
\hline & $\mathrm{t}$ & \multicolumn{2}{|c|}{2,66} & \multicolumn{2}{|c|}{3,48} & \multicolumn{2}{|c|}{3,76} & \multicolumn{2}{|c|}{4,16} \\
\hline & & & & $t_{k y p}=$ & $p=0$ & & & & \\
\hline
\end{tabular}


Ригідність перцептивно-мисленнєвих процесів, яка виражається в нездатності до створення нових форм, відбивається також і на рівні конструктивної діяльності. Оцінка цього показника по окремому малюнку в роботах підлітків експериментальної групи становить у половині випадків 0-1 бал, і ніколи не перевищує 2 бали. Інакше кажучи, у процесі створення образу, досліджувані залишаються в межах заданої форми, у той час як висока оцінка конструктивної активності (3 бали) передбачає значні видозміни як всередині, так і зовні форми. Така обмеженість конструктивних можливостей свідчить про значну залежність візуального мислення підлітків експериментальної групи від заданого перцептивноого поля.

У деяких роботах спостерігається використання однієї ідеї (концепту) для всього ряду стимулів, що свідчить про недостатню категоріальну гнучкість. Досліджуваний К.А. (11 років) свою роботу зі стимулом «коло» побудував на основі образу-концепту «м' яч». Тобто на його малюнках зображено 8 м'ячів: дитячий, баскетбольний, футбольний, тенісний тощо. Аналогічний прийом застосував підліток 13 років С.А. Так, він пов'язав форму кола 3 образом «знак» і намалював різні знаки: «Мерседес», «Знак пацифіста», «Знак анархії». Досліджуваний Д.Ю. (12 років) використав образ-концепт «космічне тіло» («Земля», «Сатурн», «Місяць», «Комета»); Г.Л. (10 років) на більшості малюнків зобразив тварин (зайчик, ведмідь, кролик тощо). Прийом застосування одного універсального (концептуального) рішення до всього ряду фігур спостерігається в роботі і 3 іншими стимулами й зумовлює низьку оцінку за критерієм категоріальної гнучкості.

Розглядаючи показник оригінальності назви, потрібно відзначити, що він може виявлятися не тільки в оригінальній вербалізації, але і в оригінальній візуалізації образу.

Оригінальність візуалізації переважно пов'язана 3 високою конструктивної активністю, і тому образи такого типу відсутні в роботах досліджуваних експериментальної групи. Найвищі оцінки оригінальності (3 бали) зустрічаються тільки в роботі С.А. (13 років): малюнок «Цигарки» (III стимул), однак створення цього образу не потребує значної конструктивної активності. Ще один приклад такого ж типу: «Струни гітари» (при цьому показник конструктивної активності становить 0 балів - підліток просто називає стимул (III)). Якщо ці малюнки й отримують вищу оцінку, то саме за вербальну оригінальність. Досліджуваний С.А. отримав найвищий бал також за ці назви: «Мексиканець», «Туалетне каченя» (II стимул). Образи «людина» і «птах», які послужили базисом даних малюнків, $\epsilon$ стандартними й досить часто зустрічаються в роботах інших підлітків. Саме тому ми можемо говорити тільки про вербальну, а не образну оригінальність.

Методика Равена. Діагностика операційної сфери візуального мислення показала нездатність підлітків експериментальної групи до побудови складних багатокомпонентних операційних низок. Ця особливість виявилася вже в процесі розв'язання завдань серії А, хоча вони $є$ найпростішими. Принцип, який лежить в основі цієї серії, - співставлення фігури та фону - всі досліджувані зрозуміли добре. Тому завдання А1-A7, в яких використовується фон 3 монотонною графічною структурою, не викликали труднощів. У матрицях А9-А11 автор тесту ускладнює графічну структуру фону. Тобто розв'язання даних завдань потребує здійснення додаткових аналітичних дій, які збільшують операційну низку. Досліджувані експериментальної групи не зуміли застосувати ці додаткові дії.

Спостереження під час тестування показали, що підлітки 10-11 років взагалі не змогли здійснити аналіз графічної структури фону, а підлітки середнього віку (12-13 років) виявили особливості фону, але добрали невідповідну фігуру.

Після тестування ми провели бесіду з підлітками експериментальної групи з метою виявлення структурних компонентів візуального мислення, включених в алгоритм розв'язання даного виду завдань. Для цього ми використали метод підказки. Він полягав у тому, що експериментатор пояснював підліткам принцип, за яким побудовано серію, на прикладі першої задачі, і після цього пропонував самостійно знайти правильне рішення, застосовуючи цей принцип. У результаті в експериментальній групі виявилося 3 типи досліджуваних: 
експериментатора;

підлітки, які успішно виконали наступні завдання серії після підказки

- підлітки, які успішно використали виявлений принцип для аналізу структури матриці, але не зуміли застосувати його для побудови потрібної фігури;

- підлітки, які розв'язали тільки ту задачу, яку пояснив експериментатор, i не зуміли застосувати вказаний принцип для вирішення наступних завдань серії.

Саме в мисленні підлітків третьої групи найменш розвинена здатність до формування складних операційних низок.

Піктограма. Як ми вже відзначали раніше, результати, отримані за методикою Фідлера, не можна віднести до «низьких» або «високих», тому що вони відображають індивідуальні особливості візуальної мисленнєвої діяльності, і кожен адекватний образ $є$ прийнятним. Проте необхідно звернути увагу на те, що все ж таки є деякі характерні риси, які вирізняють роботи підлітків експериментальної групи 3-поміж робіт інших досліджуваних.

По-перше, візуалізацію стимульних понять підлітками було здійснено в основному за допомогою малюнків сюжетного характеру, які передають образи-уявлення. Переважно, це зображення конкретних ситуацій з певною кількістю дійових осіб. Наприклад, 10-річний М.I. для візуалізації поняття «страх» малює людину і тварину, тобто ситуацію, яка викликає страх. Аналогічний сюжет використав 13-річний П.О.: людина і таргани. У зображенні тварини особливо виділені щелепи - гострі, непропорційні великі.

Друга особливість, якою відзначаються роботи підлітків експериментальної групи, відсутність міміки в зображенні облич. Наприклад, люди намальовані у вигляді схематичних фігурок (Ю.Ю., 10 років). Якщо зображено риси обличчя, то часто вони мімічно нейтральні. Зустрічаються також малюнки 3 неадекватною мімікою. Так, 13-річна Т.О. для передачі таких понять, як «радість», «щастя» та «смуток», «страх», використала фігуру людини, за мімікою й одягом дуже схожу на клоуна, хоча дані поняття протилежні за своїм емоційним наповненням. Цікаво відзначити, що ці малюнки досліджувана виконала кольоровими фломастерами, для всіх зображень використовуючи тільки яскраві, життєрадісні кольори.

Висновки і перспективи подальших розвідок. Отже, аналіз отриманих даних, результати якого представлені, дав нам можливість оцінити рівень розвитку візуального мислення підлітків як по якісних, так і по кількісних показниках. Було визначено реальний рівень розвитку процесуальних характеристик, операційних структур та змістових компонентів візуального мислення підлітків, а також підтверджено, що на різних етапах підліткового віку здатність до створення образів та оперування ними змінюється за рівнем складності, що є підставою для визначення вікових особливостей розвитку візуального мислення підлітків. Отримані результати дозволяють розкрити напрямки стимулювання візуального мислення.

\section{СПИСОК ПОСИЛАНЬ}

Роэм, Д. (2013). Визуальное мышление. Как продавать свои идеи при помощи визуальных образов. Москва: Манн, Иванов и Фербер, Эксмо.

Симоненко, С. М. (2005). Психологія візуального мислення: Стратегіально-семантичний niдxid. Одеса: ПНУАПН України.

Черенковська, Н. I. (2014). Візуальна медіа культура: Розвиток критичного мислення $i$ творчого сприйняття: Метод. рек. Київ: МІЛЕНІУМ.

\section{REFERENCES}

Roem, D. (2013). Vizualnoe myishlenie. Kak prodavat svoi idei pri pomoschi vizualnyih obrazov [Visual thinking. How to sell your ideas with visual images]. Moskva: Mann, Ivanov i Ferber, Eksmo. [in Russian]. 
Symonenko, S. M. (2005). Psykholohiia vizualnoho myslennia: Stratehialno-semantychnyi pidkhid [Psychology of visual thinking: A strategic-semantic approach]. Odesa: PNUAPN Ukrainy. [in Ukrainian].

Cherenkovska, N. I. (2014). Vizualna media kultura: Rozvytok krytychnoho myslennia i tvorchoho spryiniattia: Metod. rek. [Visual media culture: The development of critical thinking and creative perception]. Kyiv: MILENIUM. [in Ukrainian].

\title{
PSYCHOLOGICAL ASPECT OF FORMATION OF VISUAL THINKING IN ADOLESCENT STUDENTS
}

\author{
O. Ivaniuta \\ Candidate of Psychological Sciences, \\ Associate Professor of the Department of Psychology \\ International university of economics and humanities \\ academician Stepan Demianchuk \\ https://orcid.org/0000-0002-3316-9879
}

\author{
O. Yanytska \\ Candidate of pedagogical sciences, \\ Associate Professor of the Department of Psychology \\ International university of economics and humanities \\ academician Stepan Demianchuk \\ https://orcid.org/0000-0003-4965-1720 \\ DOI https://doi.org/10.35619/praprv.v1i15.185
}

\begin{abstract}
The present study explores the issue of individual development of visual thinking in adolescent students by the method of determining the in-group norm. Comparison of the results, obtained by Torrance test of creative thinking and Raven's progressive matrices, made it possible to determine the level of development of visual thinking and to identify adolescents with low efficiency of visual mental activity. It was extremely important for the improvement of techniques to stimulate visual thinking of adolescents.

Analyzing the qualitative features of the process, mentioned above, we have found that solving the task, children with low level of visual thinking tended to ignore the instructions, have inflexible perception and thinking processes, which influenced their constructive activity. They also were unable to create the complex multicomponent operating chains.

Then, we interviewed the teens of the experimental group to identify the structural components of visual thinking included in the algorithm for solving problem. We used the" hint method"( the adolescents were told the principle on which the task series was built, on the example of the first problem, and then they were offered to find the right solution on their own, applying this principle. As a result, the experimental group was divided into 3 subgroups:

1) adolescents, who have successfully completed the following tasks of the series after the experimenter's hint;2) adolescents, who have successfully used the identified principle to analyze the structure of the matrix, but failed to apply it to build the desired figure;3) adolescents, who have solved only the problem explained by the experimenter, and failed to apply this principle to solve the following problems in the series.

Thus, our study determined the real level of development of procedural characteristics, operating structures and content components of visual thinking of adolescents and confirmed that at different stages of adolescence the ability to create images and operate with them varies in complexity.
\end{abstract}

Key words: visual thinking, adolescents, in-group norm, Torrance test of creative thinking, The Raven's progressive matrices. 